GARY GENOSKO

\section{introducing deleuze}

\begin{tabular}{|c|}
\hline CLAIRE COLEBROOK \\
\hline Understanding Deleuze \\
\hline Allen \& Unwin, Sydney, 2002 \\
\hline ISBN 1-86508-797-1 \\
\hline RRP \$35.00 (pb) \\
\hline
\end{tabular}

A few years ago I was asked by an editor of the cultural studies list at Routledge's London office to edit a three-volume collection of critical literature on Deleuze and Guattari. The prospect that cultural studies might lay claim to Deleuze and Guattari was perhaps predictably met with consternation by editors of the philosophy list. For what strange creature would result from the meetings of Deleuze, Guattari and cultural studies? But this was precisely what interested me as an editor. I am not alone in this. The same question interests Ian Buchanan, who 'wonders what a Deleuzian, that is, transcendental empiricist cultural studies would look like'. ${ }^{1}$ And it is also what interests Claire Colebrook, enough for her to publish two 'introductory' Deleuze books in the same year-this one for a cultural studies list and the other for literary studies. ${ }^{2}$ Colebrook poses the problem of what cultural studies would look like with a Deleuzian conception of difference instead of the negative one it has inherited from structuralism's logic of representation (where images are yoked to a preimaged foundation).

While contextualising Deleuze's philosophy in such studies could be unDeleuzian because it would make texts mean instead of allowing them to work (that is, concepts might be put up on blocks, leaving them to rust, like a brokendown car), as Colebrook well knows, her pursuit of the task is for that reason no less genuine. Introductions have the potential power to arrest a thought's becoming, as do glossaries (which the book contains up front), for the sake of what an introduction is-formatted, acceptable, publishable, profitable-in conformity with an image of its passive readership. We used to ask 
ourselves in semiotics: how many times can one introduce C.S. Peirce's thought? An introduction, in short, may be a motor of thought that won't turn over and, even if it did, its wheels are no longer touching the ground. As Colebrook acknowledges: 'the problem with any introduction to Deleuze is that it will have to use all those methods, of metaphor, generalisation and example, against which his thought was directed'. (94) This is not fatal, of course, but one has to be careful about which examples (for instance, one's own?) can be generalised.

Deleuzian philosophy has for Colebrook a kind of Marxian imperative to transform life. Thinking is embedded in life's fluxes and, far from being static, is transformative and complicating, leading the way to what life might become, in all of its pulsing, chaotic nuances. This is the direction that Colebrook points her readers, bringing out that the challenge of Deleuzian thought is to 'see life as a problem', in fact, a series of problems that thinking encounters and ceaselessly produces: historically, for instance, structuralism, political representation and the politicisation of representation (especially the 'expanded perception' of the forces, histories, assumptions, prejudices, and powers beyond ourselves producing the world we inhabit). This approach is expressed by the keyword difference as variously prehuman or inhuman (focusing on geologic or technologic). Philosophy's work is to create and assess concepts that allow for the emergence of difference.

There is, as Colebrook underlines, a radical decentering of the human in Deleuze: 'we need to rethink the notion of the human decision; for it is less the case that we decide who "we" are than that forces "decide" us'. (xlii) We may thus add Deleuze to that pantheon of thinkers who exploded the naive self-love of human beingCopernicus-Darwin-Freud (self-nominating)_ in getting beyond and before and aside 'the human point of view'. Yet this is too handy an account. Deleuze swerves from Darwin (and then from Freud), as Colebrook explains, in his efforts to get 'beyond' representation as a kind of 'common sense' about the subject's duty to copy the external world into thought (in a nutshell, representation domesticates difference). To this end she deploys the example of the virtual power of evolution conceived as 'a capacity or potential for change and becoming which passes through organisms' (2) against a maintenance and selection model focused on the creation of species and organisms. Further, Colebrook shows how Deleuze sought in traditionally non-philosophical thought-like stupidity in the pursuit its own perversities - a way around common sense (dominated by 'dogmatic image[s] of thought'). Indeed, the two great models of differencegenetic and dialectical as opposed to synchronic and structural-were accepted by Deleuze as problems (13) without acceding to the consequences of an orientation either towards an origin (consciousness) or system (language). Rather, the ground of Deleuzian difference is itself. Thus, this difference is 'positive' and thinking about it in this manner is difficult (an 'eternal challenge', 14) against the tendency of common sense to fall back upon 'already given entities' and subordinate difference to fixity, sets of relations and representation. For 'difference is itself different in each of its affirmations', which entails it is neither common nor systemic. (27) 
Colebrook very delicately parses ideas of difference in their negative forms through discussions of structuralism and psychoanalysis in order to get to the positive Deleuzian version (though she seems overgenerous to Lévi-Strauss in emphasising his sociological apprehension of the generative power of collective life which is hardly original to him, 18). She explains why Deleuze rejects a conception of desire as lack based on a negative conception of linguistic difference and its oedipal (ultimately capitalist) prohibitive coding_-difference [is] a law [of the father] to which we are subjected, a law that deprives us of immediacy and presence [of the lost plenitude of the mother's body]'. (24) A positive conception of difference cannot be grounded on an absence (or perhaps equally, an illusion of an 'undifferentiated ground' outside difference, 30ff) whose recovery a human being forever strives to regain, which thus makes the death drive fundamental for psychoanalysis for such a recovery is the loss of self; neither is difference reducible to that which emanates from an undifferentiated source. 'Life itself is differential ... and difference is singular because each event of life differentiates itself differently'. (28)

The implications of Deleuze's offer of, then, only internal or immanent, as opposed to external or transcendent, explanations of difference, are pursued with great rigor and clarity through the topics of Deleuze's transcendental method, the univocal plane of becoming, desire, synthesis of flows into stable identities, intensive, productive and connective sexual difference, and how language reduces difference. It would have been interesting if Colebrook had considered the internal diversity of structuralism because it comes off as a kind of monolithic difference arrester. I also appreciated how she got Guattari into the mix by pointing out that he directly politicised Deleuze's philosophical analyses of perception and difference. (34) But more work is undoubtedly needed on this point because Guattari is barely a factor when the discussion turns to micropolitics and the important distinction between subjugated and subject groups (58ff); although the latter loses none of its political import as Colebrook very successfully reloads it with problems of racism, nationalism and Aboriginality.

Colebrook writes: 'Deleuze's task is to think the plane of immanent difference without providing yet one more image that would explain difference in general.' (86) How not to subject difference to a single image becomes a major philosophical task for Deleuze. Thought's encounter with difference in its multiple forms engages in 'intensity management' strategies in which units are abstracted, flows are connected, intensities composed, and beings are produced. Deleuze asks us to think past these 'molar formations' to the qualities (contracted and elevated) of which they consist in the effort to confront difference. In the process, philosophy changes in each encounter with difference; this makes it interdisciplinary, as Colebrook explains, in an elevated sense (creative and affirmative) beyond simple borrowing and novel combinations of concepts without any real commitments beyond writing grants. Philosophy never rests in its effort to conceptualise the ways in which, and how, difference is revealed in each event, work, perception. A warning, of sorts, follows: 'The minute we take any voice as exemplary we have 
elevated one particular mode of thinking and speaking as a general model. We have ceased to think.' (97)

It is likewise for desire. A single form of desire (the 'miserable story' of lack) 'turns against life'. (100) It is necessary to turn away from lack, away from the subject-object division, towards life as desire and flow, loosened from representation, back to the prepersonal flux before the formation of subjects who desire, into the world of productive differences in their potential to differ. It is in this turn to the prepersonal (connective synthesis) that Deleuze differs from Foucault, for instance, in discussing the regimes of desire (disjunctive and conjunctive syntheses). (107-10) Colebrook walks her readers through the desiring machines, the forms of syntheses and the ways they may be understood (socially, historically, politically) both legitimately (immanently and schizoanalytically) and illegitimately (transcendently and psychoanalytically). Just as she earlier included a short example from William Blake of how to proceed with a Deleuzian reading of a poem on the basis of immanence, here she tries out a short poem by Sylvia Plath as an example of how to eschew metaphor in order to learn how the poem works schizoanalytically. (136ff.) There is a missed opportunity here to flag Deleuze's fascinating theory of writing and affect in his readings of Jarry, Whitman, Melville and others (beyond his better known work on Proust, Kafka, Carroll and Artaud as he fleshed out the myriad possibilities of minorisation). ${ }^{3}$

There is a point at which the problem of the introductification, if you will, of Deleuze rears its head. In her discussion of the emergence of the signifier from the graphic material flows, as one example of how the syntheses may be understood and how it assumes a transcendent power in relation to the surplus value of meaning, Colebrook suggests to us that this is the very question of how the sign of Deleuze's thought that she is producing will be taken. For the signifier, as she points out, becomes despotic because it 'presents itself not as the production or synthesis of relations and transformations but as the representation of some preceding meaning. Western culture in general suffers from this "interpretosis".' (120) The replacement of a frozen 'Deleuze' by the sign of the introduction is a grave danger for the academic writer as reading is then displaced onto secondary and tertiary sources and thinking becomes 'canned', like elevator music or pathetic introductory level lectures. This is not inevitable and I do not wish to exaggerate the danger, but it is there nonetheless.

Colebrook then turns her attention to the role of perception in the 'non-interpretive' approach to life: 'Perception is used by Deleuze in its broadest possible sense, as a connection, interaction or encounter with the plane of life.' (140) Perception is an event grasped molecularly, but on a continuum right up to the human brain (the theatre in which actuality is screened) that slows down, delays and mediates perception, in the process forming assemblages (for example, faciality) and overcoding them (for example, the hand withdraws and becomes a tool) with the assistance of technical machines. The technical machine at issue is cinema, which can be used to perceive perception through certain images of movement and time. Colebrook writes elegantly and insightfully on slowness in perception- 
slowing down perception introduces order. Cinema 'mobilizes perceptions' (149) and gives access to movement that our perception otherwise immobilises (that is, locates in point of view). The virtual for Deleuze is an inhuman power of slowness. (168) The two images of cinema-movement- and time-image-keep space open and mobile and reveal the possibility of experiencing the duration of time, that is, a virtual, differing time-a time 'untamed' by order, sequence and spatialisation, (159) a time that is disruptive of actuality.

Cultural studies as it is practiced today has difficulty confronting immanence; immanence is the 'crucial idea' (57) of Deleuze's philosophy. Cultural studies needs, from a Deleuzian perspective, to be overcome or at least learn to modify its reliance on representational thought and open itself to reinvention, becoming able to respond to the dynamically open flows and becomings of life, in all their varying speeds and durations and potentialities, beyond the human, which is 'just one type of imaging or perception among others'. (69) The positive power of Deleuzian thought, thinks Colebrook, may help cultural studies overcome the 'dogma of representation' by levelling the distinction between reality and its representation and the actual and virtual such that they coexist (series over sequence; simulacra without ground).

Colebrook ends her book with a few filmic examples of what a Deleuzian alternative to the interpretive problems of interpretation (the political meaning of narratives) might entail. This amounts to a fundamental reorientation towards how intensities (for example, non-narrative) are composed and coded and invested in styles.
Prepersonal investments produce politics prior to meaning. This approach is, as Colebrook admits, a 'strict formalism', (180) but she does not address formalism as a problem beyond deflecting the implication that Deleuze's choice of high modernist works (and here and there she boldly dismisses postmodern works), limits his and our own vision of art's ability to expand perception and see differently. Another book can take up Deleuzian formalism as a problem. Reading Colebrook prepares us for this task.

GARY GENOSKO is Canada Research Chair in Technoculture Studies, Lakehead University, Thunder Bay. His latest book is The Party without Bosses: Lessons on Anti-Capitalism from Félix Guattari and Luís Inácio 'Lula' da Silva, forthcoming from Arbeiter Ring, Winnipeg, Canada.

1. Ian Buchanan, 'Deleuze and Cultural Studies', in Gary Genosko (ed.), Deleuze and Guattari: Critical Assessments of Leading Philosophers, vol. 1, Routledge, London, 2001, p. 17.

2. See her Gilles Deleuze, Routledge Critical Thinkers, Routledge, London, 2002.

3. I am thinking primarily of the essays in Critical and Clinical, trans. Daniel Smith and Michael Greco, University of Minnesota Press, Minneapolis, 1997. These essays are compact and beautifully crafted. I want to qualify this claim by noting that Colebrook does devote a chapter to minor literature in her other Deleuze book, Gilles Deleuze, pp. 103-23. 